\title{
The Relationship between Economic Growth and Unemployment Rates: Validation of Okun's Law in Panel Context
}

\author{
Despina Tumanoska ${ }^{1, *}$ \\ ${ }^{1}$ FINANCE THINK - Economic Research \& Policy Institute, Str. Frederick Chopin 1/2, 1000 \\ Skopje, Republic of North Macedonia \\ *Corresponding author: FINANCE THINK - Economic Research \& Policy Institute, Str. \\ Frederick Chopin 1/2, 1000 Skopje, Republic of North Macedonia. Tel: 389-75-336-174. E-mail: \\ Despina.tumanoska@financethink.mk
}

Received: March 3, 2020 Accepted: March 19, 2020 Published: March 24, 2020

doi: 10.5296/rae.v12i1.16665 URL: https://doi.org/10.5296/rae.v12i1.16665

\begin{abstract}
This paper investigates the relationship between economic growth and unemployment rates of total and youth population in panel context. The research is in context of Okun's Law and includes two panels: 1) Panel composed of seven South Eastern European countries and 2) Panel composed of 14 EU members' countries whose youth unemployment rate in 2017 was below the EU average rate. The econometric analysis of the paper is based on the Autoregression Distributed Lags Model, using data for the period 1991-2017. The results suggests that there is a statistically significant relationship between the economic growth and unemployment rates in both panels, whereas the relationship is stronger in the EU panel, while the adjustment of the unemployment rates to the changes in the economic growth is faster in the SEE panel. A part of this result can be explained by the more flexible labor market institutions in the developing countries, as those that are a part of the SEE panel.
\end{abstract}

Keywords: Okun's Law, economic growth, unemployment rate, youth unemployment, panel context, ARDL model 


\section{Introduction}

The relationship between the economic growth and the unemployment rate was studied by a Yale Professor Arthur Okun, for the first time in 1962. His research postulated the Okun's Law that predicts that $1 \%$ increase in the growth rate above its trend rate will lead to only $0.3 \%$ reduction in the unemployment rate. Okun estimated two models of his law, the difference and the gap model, which are considered as original ones. Both, assumed that to produce more products and services within the economy, more labor is required.

Later, many economists argued that the labor may be increased not only through hiring new workers, but also through increasing the number of hours worked, the level of productivity, etc. Also, the current level of unemployment may be determined by the unemployment rates in the past. According to these arguments, the existing models were upgraded with additional independent variables. Later, two more models of Okun's Law were designed: the dynamic and the production function model. The dynamic model includes lags of economic growth and unemployment rate, since it predicts that the past values of the variables, growth and unemployment, may affect the current unemployment rate. The production-function model is even wider and includes variables that combine the labor, capital and technology.

Okun's research of the relationship between economic growth and the unemployment urged many economists to investigate this causality in different countries for different time periods. At the very beginning since the postulation of the Law, many economists tried to re-estimate the relationship in the United States (Smith, 1974; Gordon, 1985; Knoester, 1986). Later, intentions to test the relationship between these two variables in other countries were recorded (Kaufman, 1988; Moosa, 1997). Most of them, only confirmed the negative relationship between the economic growth and the unemployment rate, but the strength of the relationship varied by country. On the other hand, there are studies confirming that the Okun's Law is not valid elsewhere, estimating non-significant relationship between the growth and unemployment, rather than finding a positive relationship between the variables. Last, there are economists who considered that the Law is not accurate given that many other variables need to be included in the model.

However, almost all economists agreed that the relationship between the economic growth and unemployment rates are explained through the demand side, meaning that the boosted aggregate demand will cause an increase in the production. This process will seek for bigger contingent of labor and therefore a decrease in the unemployment rate. Vice versa, a negative economic shock and decreased need for production will reduce the demand for labor and will cause an increase of the unemployment rate.

This paper seeks to estimate the relationship between the economic growth and the unemployment rates of total and youth labor force, in two panels composed of countries at different income and development level. In continuation, the next section briefly reviews the available literature in connection with the Okun's Law. Section 3 gives a descriptive analysis of the variables of interest. Section 4 describes methodology and gives the results of the research. The last section concludes the paper. 


\section{Empirical Analysis Review}

Using different sets of countries and time periods, many economists estimated the relationship between the two core variables of the Okun's Law: economic growth and unemployment, showing that there is a cross-country heterogeneity in the Okun's coefficient due to some country-specific factors like the existing labor market institutions, regulation and/or its flexibility, economic structure, population structure, different production and income level. Therefore, each country's labor market reacts different to the changes in the business cycle.

Also, the literature is rich with papers that use the unemployment rate of youth as an independent variable, in order to estimate its relationship with the country's economic growth, in context of Okun's Law. Many of them suggest that the youth unemployment rate is more sensitive to the economic cycle compared to the unemployment rate of older age cohorts, mainly because youth are less experienced, probably engaged with temporary contracts and/or less protected by the employment institutions (Dietrich, 2012). So, companies face lower opportunity costs when firing a young worker.

\subsection{Relationship between Economic Growth and Total Unemployment}

Farole et al. (2017) estimated the relationship between unemployment rate and GDP growth in 176 countries, using data for the period 1993 - 2015 and found that the value of the Okun's coefficient vary across countries and decreases by income groups. Ball et al. (2019) estimated the validity of Okun's Law in 20 advanced countries and found that the Law is valid elsewhere, but there are significant differences in its value, mainly due to the elasticity of the labor market in each country, rather than the employment protection regulation. Hanush (2013) investigated the relationship in eight East Asia countries with different income level. Findings suggest that the economic growth creates new jobs, but the extent differs among countries due to the differences of the labor market institutions and the flexibility of rules for hiring/firing workers.

Moosa (1997) tested the Okun's Law in G7 countries, finding strongest relationship between output and unemployment in North America and weakest in Japan, explaining that the result shows the differences in labor market rigidities. The higher coefficient in North America means that its employment policies are more flexible compared to those in Japan. Lee (2000) made a cross-country estimation of the Okun's coefficient in 16 OECD countries, and as Moosa (1997), he found the lowest coefficient in Japan explained by the rigidity of the Japanese labor market. Boulton (2010) found the significant relationship in five out of nine EU countries, where the Okun's coefficient took value around -4 . He found a positive relationship between the GDP growth and unemployment rate in Poland and Latvia, explained with the decreased labor force and increased unemployment rate within the investigated period.

Huang and Yeh (2013) estimated the existence of Okun's Law in panel context and found significant negative Okun's coefficient for the OECD panel, but significant positive relationship between unemployment and GDP in non-OECD panel of countries. The estimated Okun's coefficient shows that for $1 \%$ change in the logarithm of the GDP, the unemployment rate will decrease for 2.9 percentage points. The positive coefficient for the panel composed of non-OECD countries means that on a long-run there is no trade-off between the economic 
output and unemployment rate. Soylu et al. (2018) estimated the Okun's Law for a panel composed of eight Eastern European countries and found an Okun's coefficient of -0.08.

Ozel et al. (2013) investigated the relationship between GDP growth and the unemployment in G7 countries, for the period 2000 - 2011 divided in two sub periods, pre and post crisis. They found that the output growth has decreasing effect on the unemployment in both periods, but it is stronger in the post-crisis period. The latter was confirmed by Novak and Darmo (2019) who investigated the impact of the 2008 financial crisis on the relationship between unemployment and economic output in 28 EU countries. They estimated higher Okun's coefficient in the postcrisis period, meaning that the unemployment rate, from 2008 onwards, was more sensible to the GDP growth.

\subsection{Relationship between Economic Growth and Youth Unemployment}

Economists argued that young people are more sensible to cyclical shocks because they are less protected, possess lower company-specific skills, companies faces lower opportunity costs when firing youth (O'Higgins, 1997; Bell and Blanchflower, 2011; Unt, 2012). On the other hand, in case of positive economic shock, young people fall in experience trap, meaning that they compete with older people who have more experience and skills, and are usually chosen by the employers. Besides attempts for estimating the relationship between total unemployment rate and GDP growth, there is also a specific literature which investigates the relationship between the youth unemployment and the economic output, in terms of Okun's Law. For instance, Gocer and Erdal (2015) estimated the relationship between youth unemployment and economic growth in 18 Central and Eastern European countries, and found that a one point increase above average economic growth rate is associated with a $1.13 \%$ decrease in youth unemployment. Dunsch (2016) tested the validity of Okun's Law in terms of youth unemployment in two developed European countries: Germany and Poland and found a negative Okun's coefficient, whose value is bigger for young people compared with other age cohorts. But, a difference between the countries were found; the estimated Okun's coefficient in Poland is larger than the one for Germany, meaning that youth people in Poland are more prone to economic shocks compared to their German peers. That young people are more susceptible to the economic shocks, a study by Zanin (2014) confirmed. He investigated the relationship between GDP and unemployment rates of different age cohorts in OECD countries, and found higher Okun's coefficient among people aged $15-24$ in both developed and emerging countries within OECD.

Butkus and Seputiene (2019) applied the gap version of Okun's Law to estimate the relationship between youth unemployment and GDP growth in 28 EU countries between 2000 and 2018. They confirm the validity of Okun's Law in most of the countries, but due to countryspecific factors, the estimated Okun's coefficients differ between countries. For example, their results show that a $1 \%$ decrease of GDP above its potential will cause an increase of the youth unemployment rate for 0.53 percentage points in Romania and 5.03 percentage points in Spain. 


\section{Macrothink

\section{Descriptive and Comparative Analysis}

Since the purpose of our research is to investigate the validity of Okun's Law in different panels of countries, in this section we use data on GDP growth and unemployment rates in these countries. We select a wider set of countries belonging to two panels: Southeast Europe (SEE) and European Union (EU). The SEE panel is composed of seven countries(note 1): Albania, Bulgaria, Bosnia and Herzegovina, Croatia, North Macedonia, Romania and Serbia. The EU panel is composed of EU-members countries whose youth unemployment rate in 2017 was below the 2017 youth unemployment rate in the European Union of 18.9\%. It means that this panel is composed of the following 14 countries: Austria, Czech Republic, Germany, Denmark, Estonia, Hungary, Ireland, Latvia, Lithuania, Luxembourg, Netherland, Poland, Sweden and Slovenia. The unemployment rate of young people aged $15-24$ in 2018, per country, is presented in Graph 1.

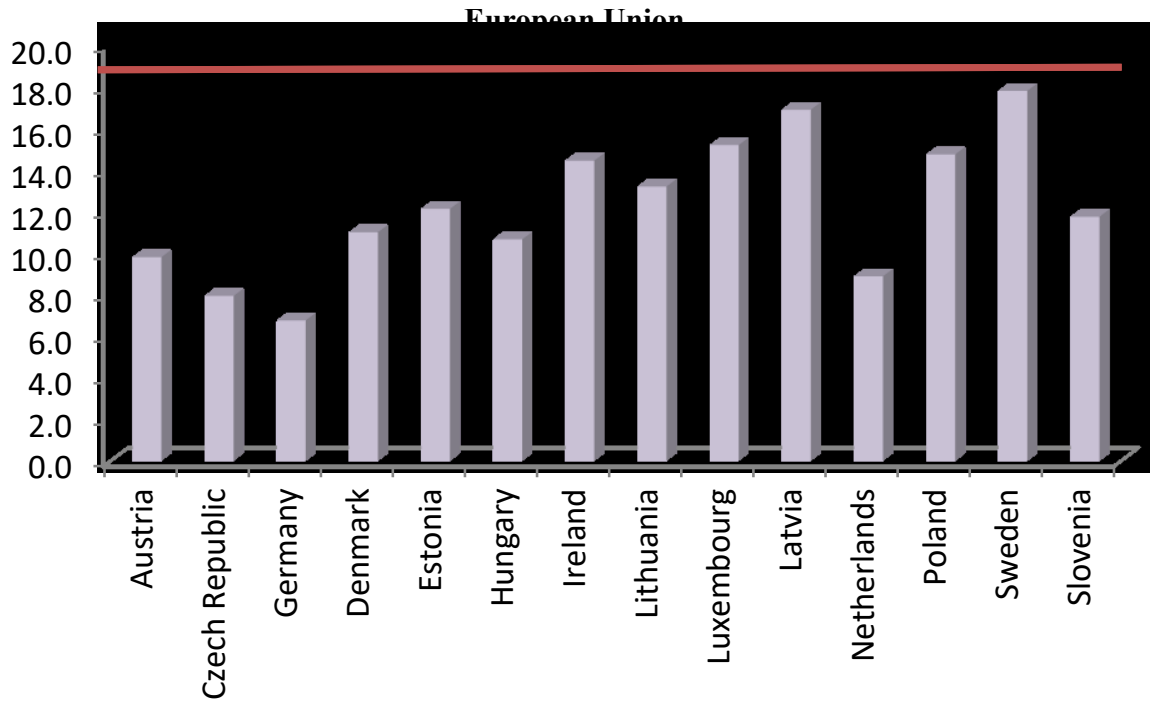

Graph 1. Youth Unemployment Rate in 2017

Source: Eurostat

According to the findings of many studies, the panels differ in their degree of development. Namely, the EU countries are characterized by higher GDP per capita and "healthier" macroeconomic indicators than the SEE countries. According to Graph 3.2, the average GDP per capita in SEE panel is USD8 500 compared to a 5-times higher average GDP per capita of USD43 300 in EU panel. 


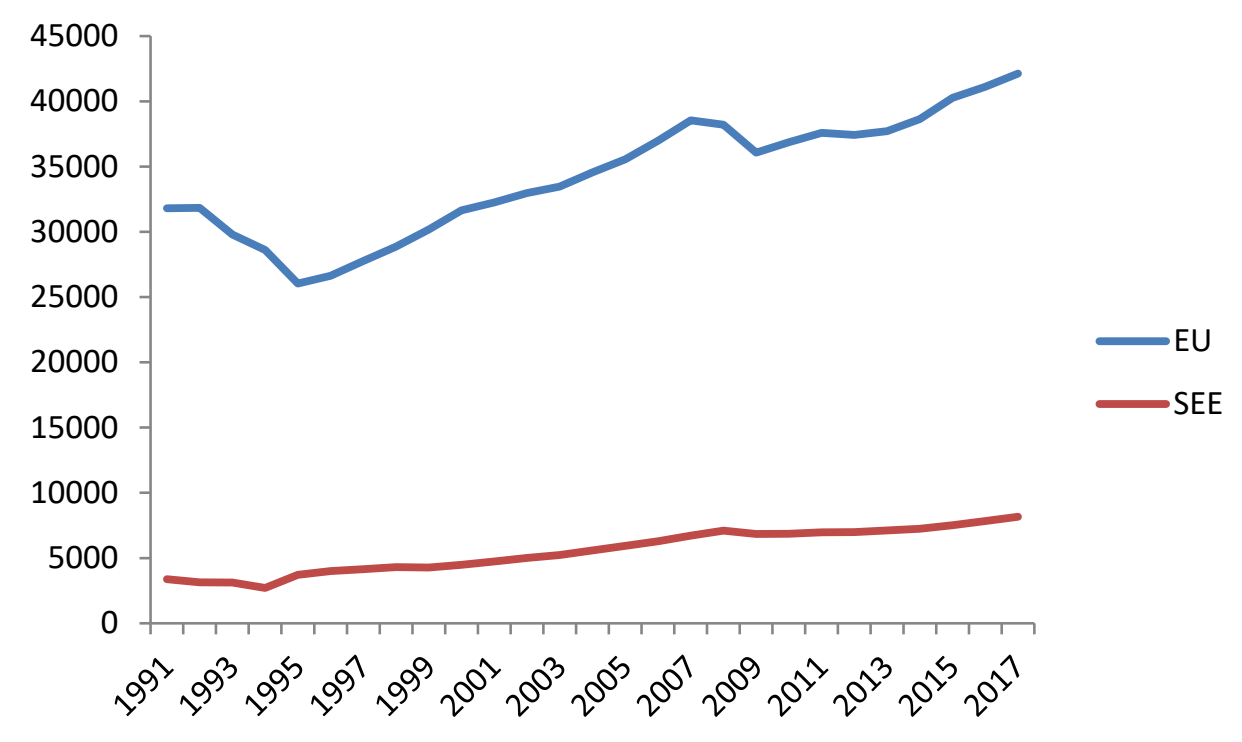

Graph 2. Average GDP per Capita in the Period 1991 - 2017

Source: The World Bank

The core components of our model are GDP growth and unemployment rates, total and youth, in the SEE and EU countries, which will help us examine whether and to what extent the changes in the economic output will cause changes in the unemployment rates. As we have already explained in section 2, there should be negative relationship between these variables, meaning that a positive change in GDP will lead to decrease of the unemployment rates, and vice versa.

If we analyze the rates of GDP growth in panel composed of SEE countries, we will notice that, except in Bosnia and Herzegovina, where the average GDP growth in the period $1991-2017$ is $10 \%$, there is no great variation between the other countries where the average GDP growth ranged between $1.4 \%$ in North Macedonia and 3.5\% in Albania. As a whole, the GDP growth in the SEE panel is 3.4\% and is bigger compared to the average GDP growth in the panel composed of EU that counts for $2.98 \%$. But, if we do not take into account the average growth of Bosnian economy, which can be considered as outlier, than, the average growth in the SEE panel will be $2.3 \%$. Among the EU countries, the variation of the average GDP growth between the countries is smaller, with standard deviation of 3.770 compared to 8.748 in SEE panel. The highest average GDP growth of 5.69\% is recorded in Ireland, followed by the growth of Baltics economies of around 4\%, whiles the lowest in Germany, $1.54 \%$. These data are shown in column 1 in Table 1.

The analysis of the average unemployment rates, shown in the last two columns in Table 1, shows that there is significant variation among countries, especially among those that are a part of the SEE panel. Namely, the average total unemployment rate in SEE panel is $17.4 \%$ : the highest is recorded in North Macedonia, 32.7\% and the lowest in Romania of $6.9 \%$. The average total unemployment rate in EU panel is more than double lower, 7.92\%. The variation 
interval from this average ranges from the lowest total unemployment rate in Luxembourg of $3.96 \%$ to the highest value in Latvia of $12.71 \%$. The greatest standard deviation is recorded among the youth unemployment rates, meaning that there are biggest differences among countries regarding the unemployment of youth aged $15-24$. In SEE countries, the average youth unemployment rate is $37.4 \%$, and it ranges from $21 \%$ in Romania to $57.1 \%$ in North Macedonia. As mentioned earlier, these two countries also recorded the lowest and the highest total unemployment rates among the SEE countries. In EU, the average youth unemployment rate is $15.4 \%$, ranging from $8.09 \%$ in Austria to $27.21 \%$ in Poland.

Table 1. Average Values of GDP Growth and Unemployment Rates in the Period 1991 - 2017

\begin{tabular}{|c|c|c|c|}
\hline Country & GDP growth & Total unemployment & Youth unemployment \\
\hline Albania & 3.5 & 16.5 & 32.9 \\
\hline Bulgaria & 1.9 & 11.8 & 27.3 \\
\hline Bosnia and Herzegovina & 10 & 25.2 & 53.8 \\
\hline Croatia & 2.2 & 12.6 & 33.9 \\
\hline North Macedonia & 1.4 & 32.7 & 57.1 \\
\hline Romania & 2.2 & 6.9 & 21 \\
\hline Serbia & 2.7 & 16.2 & 36 \\
\hline \multirow[t]{2}{*}{ Average SEE } & 3.4 & 17.4 & 37.4 \\
\hline & $(8.748)$ & $(8.681)$ & (13.992) \\
\hline Austria & 1.91 & 4.87 & 8.09 \\
\hline Czech Republic & 1.99 & 5.83 & 13.26 \\
\hline Germany & 1.54 & 7.57 & 9.30 \\
\hline Denmark & 1.65 & 6.15 & 10.33 \\
\hline Estonia & 4.18 & 8.88 & 17.05 \\
\hline Hungary & 2.02 & 8.30 & 18.35 \\
\hline Ireland & 5.69 & 9.58 & 16.75 \\
\hline Lithuania & 4.31 & 11.31 & 21.45 \\
\hline Luxembourg & 3.60 & 3.96 & 11.86 \\
\hline Latvia & 4.15 & 12.71 & 23.09 \\
\hline Netherlands & 2.07 & 4.99 & 8.85 \\
\hline Poland & 3.71 & 12.24 & 27.21 \\
\hline Slovenia & 2.68 & 7.15 & 17.16 \\
\hline Sweden & 2.20 & 7.31 & 18.83 \\
\hline \multirow[t]{2}{*}{ Average EU } & 2.98 & 7.92 & 15.86 \\
\hline & $(3.770)$ & (3.910) & $(8.012)$ \\
\hline
\end{tabular}

Source: The World Bank

Note: Values shown in brackets are standard deviation. 


\section{Macrothink

Graph 3 shows the annual average of GDP growth and unemployment rates. It is evident that in both panels, all three variables move in the same direction, with exception of the average GDP growth in SEE panel, in the period 1991-1993, due to the transition period and the independence of the ex-Yugoslav countries, and in the period 1995-1997, when a 'huge' economic growth is recorded in the SEE panel. This situation is due to the extremely high economic growth of $89 \%$ recorded in Bosnia and Herzegovina in 1996, probably as a result of the post-war expansion in the country. The stable economic growth in the world economies was disrupted by the world economic crisis that began in 2008, when most of the countries recorded negative economic growth. Therefore, in 2009, the average GDP growth in the SEE panel was $-2.8 \%$ while in the EU panel $-6.61 \%$. The same 2009 year, an increase in the unemployment rates, of total and youth labor force, was also recorded.
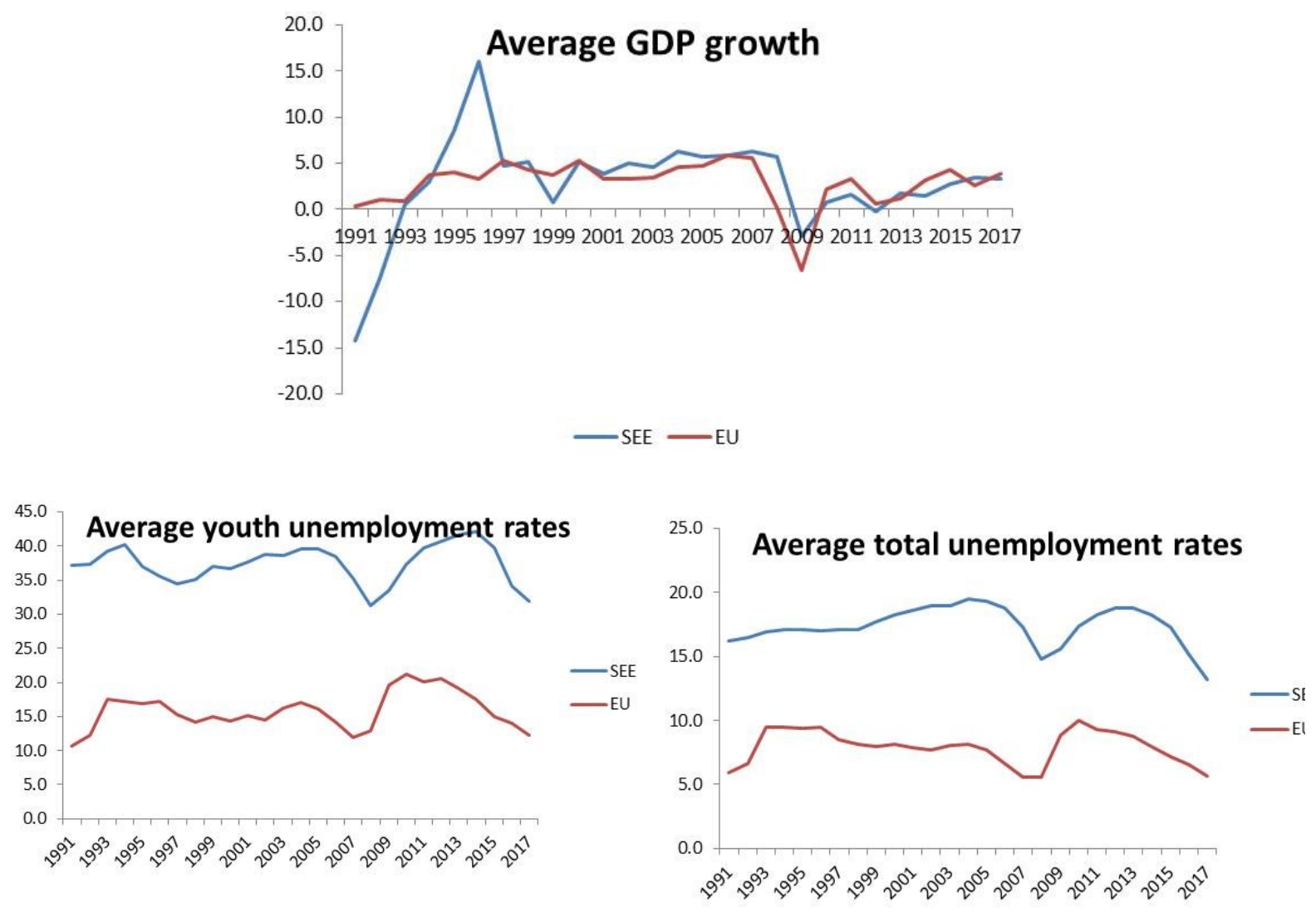

Graph 3. Average Rates in the Period $1991-2017$

Source: The World Bank

The analysis of the unemployment rates shows that both rates follow similar pattern, recording lowest unemployment rates in 2007 , that is considered as a year of economic expansion. It is evident that the unemployment started to increase in 2008, parallel with the economic crisis. In 2009, the year when a negative economic growth was recorded in both panels, an increase in the unemployment rates, of total and youth labor force, is also recorded, indicating a potential negative relationship between GDP growth and unemployment rates. The potential negative 
relationship can be seen in scatter graphs $4 a$ ) and b), which are only indicative, not showing a causal link between the variables.
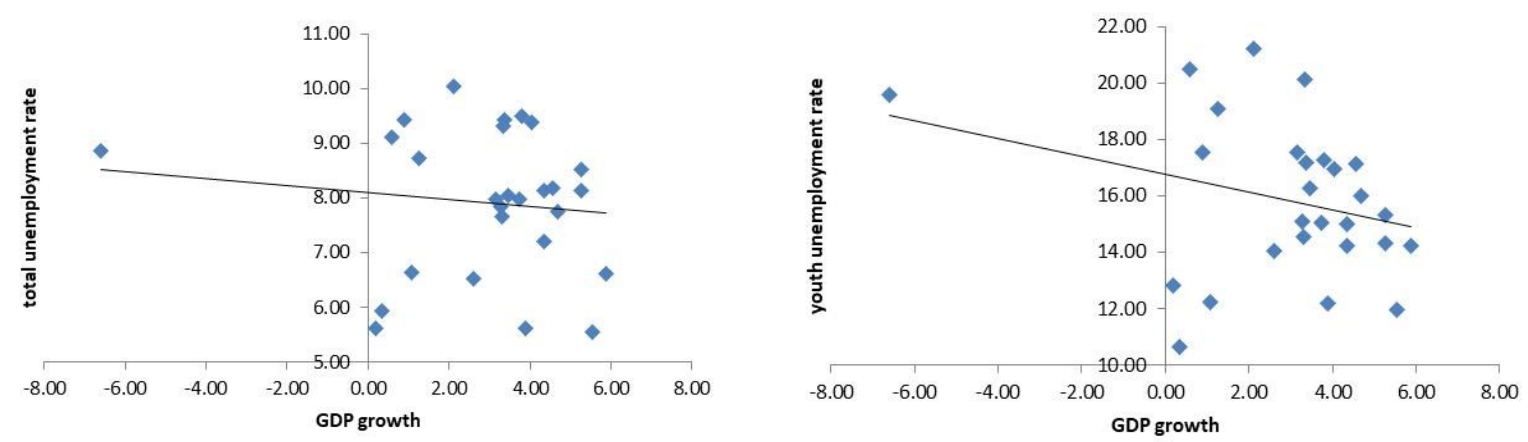

Graph 4a. The Relationship between GDP Growth and Unemployment Rates in EU Panel
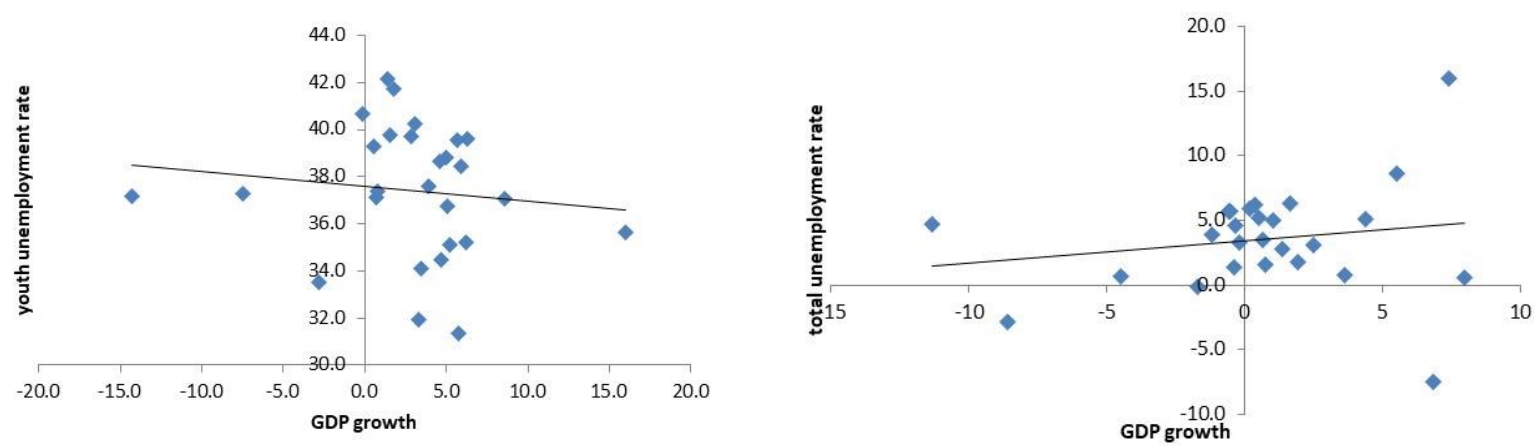

Graph 4b. The Relationship between GDP Growth and Unemployment Rates in SEE Panel

Source: The World Bank

The strength of the relationship between the economic growth and unemployment rates may be caused by several factors mentioned in section 1. Two of them are the labor participation rate and the employment institutions that we will elaborate further. The labor participation rate, of total population and youth, may be a signal of job market structure, and a weak participation rate may hint at structural weakness, and decrease the strength of the relationship between economic growth and unemployment rates. The total and youth labor force participation rates in both panels, are presented in Graphs 5a) and b). 


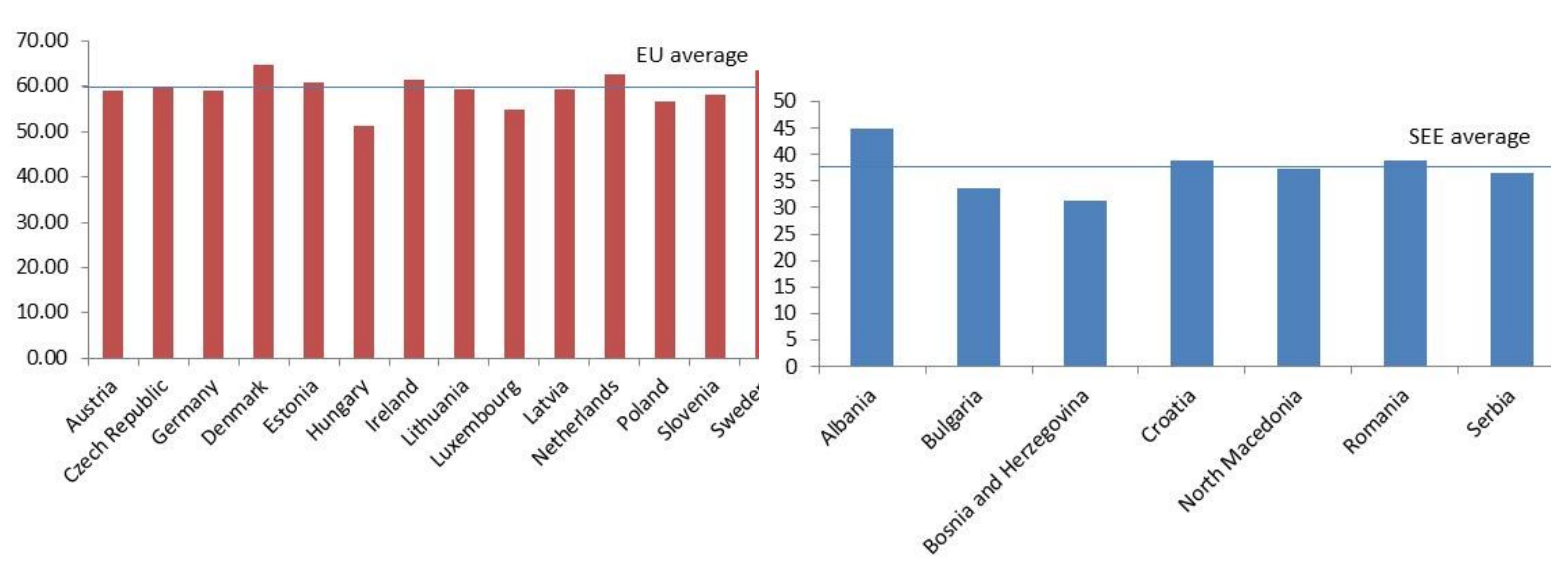

Graph 5a. Average Total Labor Force Participation in the Period 1991 - 2017

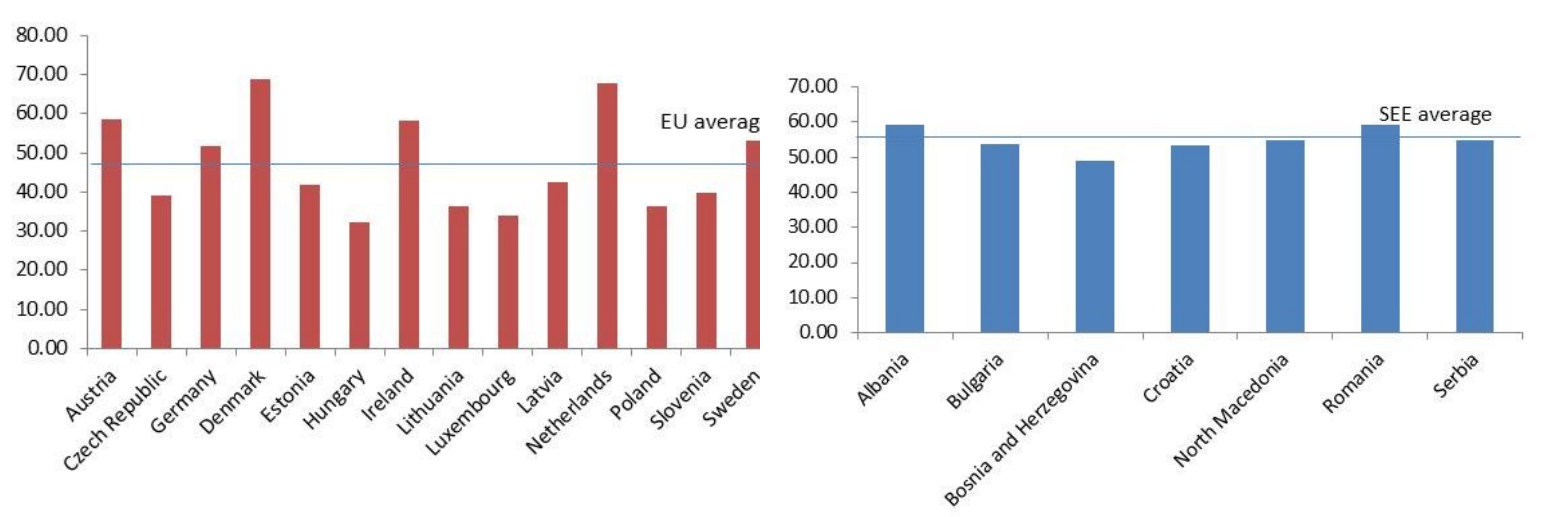

Graph 5b. Average Youth Labor Force Participation in the Period 1991 - 2017

Source: International Labor Organization

As we can see from these graphs, the average labor participation rates, of total and youth population, are much bigger among the EU countries, especially the youth labor force participation rate, ranging from $32.4 \%$ in Hungary to $68.9 \%$ in Denmark, compared to SEE countries where the youth labor participation rates are in the range $30-45 \%$. The average youth labor participation rate in EU is $47.3 \%$ compared to $37.4 \%$ in SEE panel, indicating that EU countries have greater share of youths who are economically active, and in case of economic changes there is a greater pool of labor force (employed or unemployed) who can be hired/fired according to employers' needs. The same conclusion can be drawn for the total labor force population, but the differences between EU and SEE panels are not very large: the average total labor force participation rate in EU is $59.3 \%$ and in SEE values $54.9 \%$. Based on this intuition, we can expect stronger relationship between economic growth and unemployment rates in the panel composed of EU countries.

The second factor than can influence onto the relationship between economic growth and unemployment rates are the employment institutions, composed of laws, policies and practices 
that regulate the labor market. As a measure of the employment institution we are using a part of the Economic Freedom Index developed by the Fraser Institute that measures the labor market regulation (Vasquez and Porcnik, 2019). The index of labor market regulation is composed of six indicators: 1) Hiring regulations and minimum wage; 2) Hiring and firing regulations; 3) Centralized collective bargaining; 4) Hours regulations; 5) Mandated cost of workers dismissal and 6) Conscription. The index is estimated for 162 countries and beside the indicator for labor market regulation, it is composed of 70 other distinct indicators, each ranked on a scale from zero to 10,10 representing the most freedom. Beside the value of the whole index for labor market regulation, we are analyzing the indicator of hiring and firing regulations, since in section 1 we have concluded that these regulations have significant impact on the relationship between economic growth and unemployment rates. The countries with strong regulation of the firing/hiring process face slower adjustment of the number of employees to the needs of the company, caused by the changes in the economic output. The values of both indicators are presented in Graphs 6a) and b).
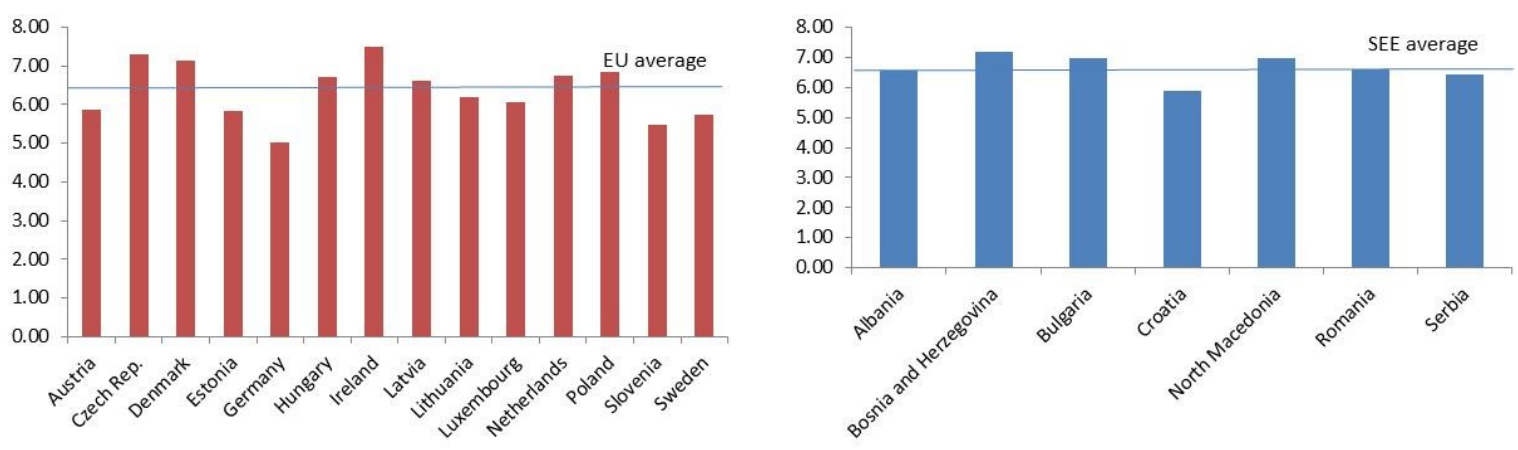

Graph 6a. Index of Labor Market Regulation in the Period 2000 - 2017
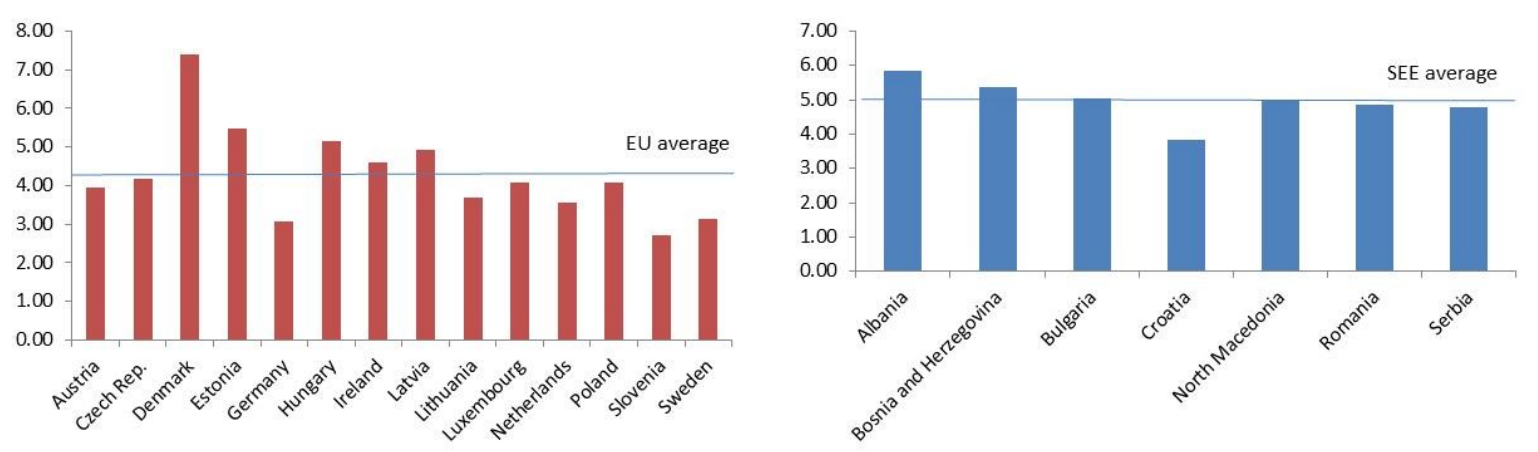

Graph 6b. Index of Firing and Hiring Regulations in the Period 2000 - 2017

Source: The Human Freedom Index 2019, Fraser Institute 
An indicator of labor market regulation or hiring/firing regulation valued 0 would mean that there is a strong regulation that impose labor market rigidity, while an indicator with value 10 means that the regulation of the countries' labor market is very flexible and employers could easily hire/fire workers according to their needs. Graphs 5a) and b) show that both indicators have higher average value in the panel composed of SEE countries and lower in those composed of EU member countries. The difference between the panels is greater in the Index of hiring and firing regulations, while the Index of labor market regulation has similar values in both panels. The index of labor market regulation in SEE has value of 6.56 while in EU values 6.36. The index of hiring and firing regulations is 5.01 in SEE and 4.28 in EU panel. This means that the labor market in SEE countries is more flexible and the rules and principles for hiring/firing workers are weaker compared to EU countries. The intuitive findings from these analysis show that we would expect a faster adjustment of the number of employees to the companies' needs, in the panel composed of SEE countries.

\section{Econometric Analysis}

According to the explanations set in section 1, the literature knows four models of Okun's Law, but only two are originally proposed and used by Arthur Okun: the difference and the gap model. The difference model regress the unemployment rate on the changes in GDP, whereas the gap version uses the difference between actual and natural unemployment, and actual and potential GDP at the same period and is used to estimate the economy production under condition of full employment. The other two models, the dynamic and production-function model use additional independent variables and data with different interpretations and assumptions.

This means that, only the difference model is pure statistical model, based on calculations using available empirical data without making assumptions. Therefore, this study employs the difference model to estimate the impact of the changes in GDP growth onto the unemployment rate. The regression is based on the original model postulated by Okun, based on the following equation:

$$
\Delta \mathrm{U}_{\mathrm{it}}=\alpha_{\mathrm{i}}+\beta_{\mathrm{i}}\left(\Delta \mathrm{GDP}_{\mathrm{it}}\right)+\varepsilon_{\mathrm{it}}
$$

where $\Delta \mathrm{U}$ is the first difference of total unemployment rate or the change in the unemployment rate from period t- 1 to $t$, in country $i, \Delta G D P$ is the first difference of the economic growth rate or the change in the economic growth rate from period t- 1 to $t$, in country $i$ and $\varepsilon$ is an error term. Central element in the equation is $\beta$, known as the Okun's coefficient that measures the relationship between these two variables.

Whereas this paper seeks to study the impact of the changes in the economic output on the youth unemployment rate, we are using equation (2) to estimate this relationship:

$$
\Delta \mathrm{YU}_{\mathrm{it}}=\alpha_{\mathrm{i}}+\beta_{\mathrm{i}}\left(\Delta \mathrm{GDP}_{\mathrm{it}}\right)+\varepsilon_{\mathrm{it}}
$$

where $\Delta \mathrm{YU}$ is the first difference of youth unemployment rate or the change in the youth unemployment rate from period $t-1$ to $t$, in country $i$. 
In this study we examine the relationship between the economic growth and the unemployment rates, of total population and youth aged $14-25$, in two panels of countries, EU and SEE panels, explained in the previous section.

In general, data for these countries cover the period from 1991 (when the SEE countries left the planned economy) until 2017. We use annual data for the total unemployment rate, youth unemployment rate and economic growth collected from the data bases of the World Bank, the International Monetary Fund and Macedonian national statistical office.

\subsection{Unit Roots}

In this section we are analysing the variables by examining their integrative characteristics, ie whether they contain a unit root. Datasets with unit roots are non-stationary and do not have constant mean, constant variance and constant co-variance over time. In the literature, tests for single- and second-generation panel unit root tests have been developed (Holmes et al., 2010). The difference is that the former are based on the assumption that the individuals are independent, meaning that there is a cross-independence between the units of inquiry (in our case countries), while the latter are based on the assumption of cross-dependence between units in the form of a single unobserved common factor. The assumption of cross-dependence in macroeconomics is particularly important given the increasing trade and financial integration of countries. The last financial crisis of 2008 showed that it can be spilled over to all countries in the world for a short time. Hence, ignoring this dependence can lead to wrong results.

As a first-generation panel unit root test we are using the Fisher test developed by Madalla and Wu (1999) while Pesaran's simple unit root tests in presence of cross-section dependence, proposed by Pesaran (2007) belongs to the second generation unit root tests, and is based on the mean of the individual t-statistic of each unit within the panel.

The results of the two single-root panel tests are presented in Table 2. If the variables are reported at level, the null hypothesis that the series have unit root is rejected only for the GDP growth, while the series for total and youth unemployment are non-stationary at level. To solve the problem of non-stationarity, we are using the first difference of the variables, and after differencing, both tests reject the null hypothesis at $1 \%$ level, for zero lag. Only lagged values of the total unemployment in both panels still remain non-stationary, according to the Pesaran test. Also, the lagged values of the youth unemployment in the panel of SEE countries are still non-stationary, when using first difference. At this moment, the results of Fisher test are more favorable, but we cannot ignore the cross-dependence between the countries. According to Table 3 where Pesaran's (2004) test of cross-country dependence is shown, it is seen that the null hypothesis of no cross-dependence is rejected in all cases. It means that the Pesaran test gives more relevant picture of the unit roots in our case. According to these findings, we have sufficient evidence to conclude that our series are likely to follow a stationary process, which means that they do not contain a unit root. 
Table 2. Panel Unit Root Tests

\begin{tabular}{|c|c|c|c|c|c|c|c|c|c|c|c|c|c|}
\hline & \multirow{4}{*}{$\mathrm{Lag}$} & \multicolumn{4}{|c|}{$\mathrm{YU}$} & \multicolumn{4}{|c|}{$\mathrm{U}$} & \multicolumn{4}{|c|}{ GDP } \\
\hline & & $\mathrm{EU}$ & SEE & $\mathrm{EU}$ & SEE & $\mathrm{EU}$ & SEE & $\mathrm{EU}$ & SEE & $\mathrm{EU}$ & SEE & $\mathrm{EU}$ & SEE \\
\hline & & \multicolumn{2}{|c|}{ At level } & \multicolumn{2}{|c|}{ First difference } & \multicolumn{2}{|l|}{ At level } & \multicolumn{2}{|c|}{ First difference } & \multicolumn{2}{|c|}{ At level } & \multicolumn{2}{|c|}{ First difference } \\
\hline & & & & & & & & & & & & & \\
\hline Fisher & 0 & 16.19 & 8.163 & $154.815^{* * *}$ & $67.027^{* * *}$ & 18.16 & 3.572 & $100.171^{* * *}$ & $40.195^{* * *}$ & $143.86^{* * *}$ & $67.927 * * *$ & $339.873 * * *$ & $267.844 * * *$ \\
\hline \multirow[t]{2}{*}{ Test } & 1 & 31.16 & $31.845^{* *}$ & $86.016^{* * *}$ & $50.860^{* * *}$ & $41.73 * *$ & $29.283^{*}$ & $101.084^{* * *}$ & $33.233^{* *}$ & $107.66^{* * *}$ & $151.207 * * *$ & $261.067^{* * *}$ & $118.832^{* * *}$ \\
\hline & 2 & 31.29 & $32.271^{* * *}$ & $44.060^{* *}$ & $30.378^{* *}$ & 37.47 & 19.257 & $45.222 * *$ & $26.882 * *$ & $54.78^{* *}$ & $33.287^{* *}$ & $116.883^{* * *}$ & $71.693^{* * *}$ \\
\hline Pesaran & 0 & 1.816 & 0.948 & $-5.966^{* * *}$ & $-3.350^{* * *}$ & 2.044 & 1.235 & $-3.784 * * *$ & $-2.145^{* *}$ & $-6.566^{* * *}$ & $-5.601 * * *$ & $-13.102 * * *$ & $-9.967 * * *$ \\
\hline \multirow[t]{2}{*}{ Test } & 1 & 1.343 & 0.884 & $-2.241 * *$ & -0.654 & 1.050 & 0.271 & -0.954 & -1.001 & $-1.285^{*}$ & $-3.441 * * *$ & $-5.660 * * *$ & $-7.121 * * *$ \\
\hline & 2 & 1.113 & 1.577 & $-0.247 *$ & -0.121 & -1.037 & 0.436 & 0.111 & -1.032 & -0.434 & $-1.958 * *$ & $-3.052 * *$ & $-3.202 * *$ \\
\hline
\end{tabular}

Source: Author's calculations.

Note: *, **, *** mean that the null hypothesis (the series have a unit root) is rejected at the 10, 5 and 1\% level. The reported values for the Madalla and Wu (1999) test are chi2 values. The reported values for the Pesaran (2007) test are Z t-bar values. Tests also include a trend, with the general conclusion from Chapter 1 that the series are trending.

Table 3. Cross-Dependence Tests

\begin{tabular}{lll}
\hline & EU & SEE \\
\hline $\mathrm{Yu}$ & $8.91^{* * *}$ & $5.46^{* * *}$ \\
$\mathrm{U}$ & $6.45^{* * *}$ & $5.67^{* * *}$ \\
$\mathrm{GDP}$ & $26.48^{* * *}$ & $7.42^{* * *}$ \\
\hline
\end{tabular}

Source: Author's calculations.

Note: *,**, *** mean that the null hypothesis (there is no cross-country dependency) is rejected at the 10, 5 and 1\% level. The reported values for the Pesaran (2004) test are $C D$ values.

\subsection{Methodology}

The findings in Section 4.1 indicated that the variables of unemployment, total and youth, and the economic growth, contain combination of stationary and non-stationary time-series. This means that we continue our analysis in order to establish the long-run relationship between the variables. In other words, we will examine whether there is a co-integrating relationship between the unemployment, total or youth, and the GDP growth. The co-integrative analysis involves separation of the short-term and long-term dynamics from the data. According to the literature (Harris and Sollis, 2003) if two variables are co-integrated, there must be an error correction mechanism that determines their joint movement.

The panel co-integration analysis has come into vogue in the last few years after the seminal work of Pesaran et al. (1999). According to our previous findings that our variables include a mixture of stationary and non-stationary time-series, the most appropriate econometric technique for estimating the relationship between the variables is the Auto Regressive Distributed Lag Model (ARDL) of Pesaran and Shin (1999) and Pesaran et al. (2001).

The Panel ARDL model is a variety of the ARDL (p, q) model in the Pesaran et al (2001) and is specified as:

$$
\Delta \mathrm{Yit}=\Phi_{\mathrm{i}}+\Sigma_{\mathrm{yij}} \Delta \mathrm{Y}_{i, t-j}+\Sigma_{\mu \mathrm{ij}} \Delta \mathrm{X}_{i, t-j}+\delta_{1 i j} Y_{i, t-1}+\delta_{2 i j} X_{i, t-1}+\varepsilon \mathrm{t}
$$


where

$$
\delta_{1 i}=-\left(1-\Sigma \lambda_{\mathrm{ij}}\right) \delta_{1 i}=\Sigma \omega_{\mathrm{ij}} \mathrm{y}_{\mathrm{ij}}=-\Sigma \lambda_{\mathrm{im}} \mu_{\mathrm{ij}}=-\Sigma \omega_{\mathrm{im}}
$$

where $\mathrm{i}=1, \ldots \ldots \mathrm{N}$ are cross-section units, in our case countries, $\mathrm{t}=1, \ldots \ldots \mathrm{T}$ are time periods, $\varphi \mathrm{i}$ is group-specific intercept and $\omega \mathrm{ij}$ and $\lambda \mathrm{ij}$ are $\mathrm{k} \times 1$ vectors for explanatory variables. The null hypothesis of no co-integration among the variables is $\mathrm{H} 0: \delta 1 \mathrm{i}=\delta 2 \mathrm{i}=0$ against the alternative hypothesis $\mathrm{H} 1: \delta 1 \mathrm{i} \neq \delta 2 \mathrm{i} \neq 0$. The null hypothesis of no co-integration is $\mathrm{H} 0$ : $\omega \mathrm{ij}=$ 0 against the alternative hypothesis $\mathrm{H} 0: \omega \mathrm{ij} \neq 0$.

The panel ARDL is performed through the following several steps:

\subsection{Selection of Optimal Lags}

The specification of the optimal number of lags to include in the model is a crucial step in the panel ARDL. First, we must decide the choice of lags for each country per variable, using the unrestricted model and an information criterion, and then to choose the most common lag for each variable to represent the lags for the model. The estimated optimal lag length is the one from Bayesian Information Criterion and shows that our model for estimating the relationship between youth unemployment and GDP growth in the panel of EU countries is ARDL (2 0 ) while the model for estimating the relationship between total unemployment and GDP growth is ARDL (1 0). Both models for estimating the relationship between variables in the SEE panel is ARDL (2 2).

\subsection{Co-Integration Test}

Panel co-integration analysis begins with the test for existing a panel co-integration relationship, originally developed by Westerlund (2007). This test comes in four versions where in the first two versions the alternative hypothesis is that the panel as a whole contains a co-integration vector, while the other two variants for the alternative hypothesis holds that at least one country in the panel contains a co-integration vector. The advantage of this test is that it takes into account the possibility of existing multiple structural changes in the series. The results of the Westerlund test for co-integration are shown in Table 4. If we analyse the results for existing a co-integration between the variables, we can conclude that all four tests reject the null hypothesis that there is no co-integration between the variables, even at $1 \%$ level. Exceptions arise within SEE panel, where the first two versions of the test reject the null hypothesis at 5\% level of probability. Generally, the analysis of the panel co-integration relationship in Table 4 provide sufficient empirical evidence that in both panels there is a co-integrating relationship between unemployment and GDP growth. 
Table 4. Co-Integration Relationship

\begin{tabular}{lllll}
\hline & EU & SEE & EU & \multicolumn{1}{c}{ SEE } \\
\cline { 2 - 5 } & \multicolumn{2}{c}{ Youth unemployment and GDP growth } & \multicolumn{2}{c}{ Total unemployment and GDP growth } \\
\hline $\mathrm{Gt}$ & $-4.574^{* * *}$ & $-3.658^{* * *}$ & $-4.614^{* * *}$ & $-2.816^{* *}$ \\
$\mathrm{Ga}$ & $-4.640^{* * *}$ & $-3.366^{* * *}$ & $-3.073^{* *}$ & $-2.892^{* *}$ \\
$\mathrm{Pt}$ & $-10.030^{* * *}$ & $-5.668^{* * *}$ & $-6.707^{* * *}$ & $-4.894^{* * *}$ \\
$\mathrm{~Pa}$ & $-13.327^{* * *}$ & $-9.688^{* * *}$ & $-12.453^{* * *}$ & $-8.288^{* * *}$ \\
\hline
\end{tabular}

Source: Author's calculations.

Note: *, **, *** mean that the null hypothesis (no co-integration) is rejected at 10, 5 and 1\% levels. Reported values are Z-values for testing the null hypothesis that there is no co-integration relationship between the variables. Two lagged values of the variables were used in the testing. The Bartlett kernel window is calculated by Newey and West (1994) as $4(T / 100)^{2 / 9} \approx 3$, where $T$ is the number of periods.

\subsection{Estimation of the Model}

The main setting of the error correction model in panel context, based on the existence of cointegration between the variables, has the following form:

$$
\Delta y_{i t}=c_{i}+\lambda_{i}\left(y_{i t}-\beta_{i x} x_{i, t-1}\right)+\sum a_{1 i j} \Delta y_{i t-j}+\sum a_{2 i j} \Delta x_{i t-j}+U_{i t} \quad U_{i t} \approx i i d N\left(0, \sigma^{2} I\right)
$$

Where $\lambda_{\mathrm{i}}$ is the error correction term / speed adjustment term, and $\mathrm{y}_{\mathrm{it}}$ is a matrix of $\mathrm{K}$ visible endogenous variables, $x_{i t}$ is a matrix of $\mathrm{M}$ visible variables. The short-term parameters are notices with $a_{i t}$, which like $\sigma 2 \mathrm{I}$ differs among countries, and $u_{i t}$ is error matrix. $\beta$ is the coefficient in front of the variables in the long-run vector and is the coefficient of main interest in our research.

According to literature, there are two estimators that solve the heterogeneity bias of dynamic panels: Mean Group (MG) Estimator and Dynamic Fixed Effect (DFE) Estimator. MG estimator, proposed by Pesaran and Smith (1995) is less restrictive and computes individual regressions for each country of the panel, deriving the long-run parameters from the ARDL model. DFE Estimator is an upgraded version of the Pooled Meaning Group (PMG) Estimator that assumes that the elements of $\beta$ are common across the countries within the panel.

The results for the $\beta$ coefficient and other parameters obtained for the panels of countries using the Mean Group (MG) Estimator and Dynamic Fixed Effect (DFE) Estimator are shown in Tables 5a) and b). The coefficient that is central to the paper is shown in the first line of the tables (in bold). The first two columns show the results for the relationship between the variables estimated using DFE Estimator, while the last two columns present the results of the relationship estimated by MG Estimator. Table 5a) shows the results of Model 1, where the relationship between youth unemployment and GDP growth is estimated, while Table 5b) presents the results of the relationship between total unemployment and GDP growth. 
Table 5a. Results for Model 1 - Dependent Variable Youth Unemployment

\begin{tabular}{|c|c|c|c|c|}
\hline & \multicolumn{2}{|c|}{ DFE } & \multicolumn{2}{|c|}{ MG } \\
\hline & EU & SEE & EU & SEE \\
\hline & (1) & (2) & (3) & (4) \\
\hline \multirow[t]{2}{*}{ GDP growth } & $-2.545 * * *$ & $-0.394 * *$ & $-2.651 * * *$ & $-0.833 * *$ \\
\hline & $(0.430)$ & $(0.208)$ & $(0.258)$ & $(0.402)$ \\
\hline $\mathrm{EC}$ - error correction & $-0.226 * * *$ & $-0.289 * * *$ & $-0.232 * * *$ & $-0.364 * * *$ \\
\hline term & $(0.032)$ & $(0.045)$ & $(0.018)$ & $(0.071)$ \\
\hline \multirow[t]{2}{*}{$\Sigma($ d.gdp $)$} & $0.121^{* *}$ & $0.098^{*}$ & $0.184 * *$ & $0.219^{*}$ \\
\hline & $(0.105)$ & $(0.076)$ & $(0.084)$ & $(0.121)$ \\
\hline \multirow[t]{2}{*}{$\Sigma($ d.yu $)$} & $0.155^{* *}$ & $0.430^{* * *}$ & $0.161^{* *}$ & $0.343^{* * *}$ \\
\hline & $(0.052)$ & $(0.071)$ & $(0.090)$ & $(0.041)$ \\
\hline \multirow[t]{2}{*}{ Constant } & $5.174 * * *$ & $11.183 * * *$ & $5.529 * * *$ & $15.178 * *$ \\
\hline & $(0.586)$ & (1.746) & $(0.668)$ & (4.902) \\
\hline No. of observations & 329 & 161 & 329 & 161 \\
\hline
\end{tabular}

Source: Author's calculations.

Note: *,**,*** means that the null hypothesis is rejected at 10, 5, and 1\% levels. Constant is included for each country. $d$ denotes a differentiated variable. Short term coefficients are reported as sums of time lags.

The results for Model 1 where the relationship between youth unemployment and GDP growth is estimated shows that $\beta$ coefficients are statistically significant at $1 \%$ and $5 \%$ level of probability, in EU and SEE panel, respectively, implying significant negative long-run relationship between these two variables in both panels. Yet, an evident difference between the estimated $\beta$ values exists. Using a Dynamic Fixed Effect Estimator (DFE) the estimated $\beta$ coefficient for the EU panel values -2.545 which means that if a GDP growth increase by 1\%, the unemployment of youth ages 15-24 will decrease by $2.5 \%$. In SEE panel, the relationship between youth unemployment and GDP growth is weaker, and the $\beta$ coefficient of -0.394 means that for any $1 \%$ increase in GDP growth, the youth unemployment will decline by only $0.39 \%$. The Mean Group Estimator (MG) gives different values that show stronger relationship between the variables, although the signs and probabilities are the same as those estimated by DFE. These estimations show that in EU, the Okun's coefficient implies negative relationship between youth unemployment and GDP growth: for any $1 \%$ increase in GDP, the youth unemployment will decline by $2.65 \%$. In panel composed of SEE countries, a $1 \%$ increase in GDP will cause $0.83 \%$ decline in the youth unemployment.

The error correction term is negative and statistically significant for both panels. This term measures the speed of adjustment toward equilibrium level and should have negative sign. The statistical significance of the term implies that the youth unemployment is driven by the GDP growth, and the negative value signs that the imbalance in their relationship is balanced after a 
shock. The estimated error correction term is higher for the SEE panels, -0.289 and -0.364 , compared to EU panel, -0.226 and -0.232 , showing that any imbalance in the relationship between youth unemployment and GDP growth will be quickly adjusted in SEE panel.

Rows 4 and 5 provide the short-term dynamic, with the cumulative coefficients reported. Their inclusion is mainly for statistical reasons, in order to take into account the possible serial correlation in the model.

Table 5b. Results for Model 2 - Dependent Variable Total Unemployment

\begin{tabular}{lllll}
\hline & \multicolumn{2}{c}{ DFE } & \multicolumn{2}{l}{ MG } \\
\hline & EU & SEE & EU & SEE \\
& $(1)$ & $(2)$ & $(3)$ & $(4)$ \\
\hline GDP growth & $\mathbf{- 1 . 4 5 9 * * *}$ & $\mathbf{- 0 . 2 4 9 * *}$ & $\mathbf{- 1 . 8 3 8 * * *}$ & $\mathbf{- 0 . 8 6 5 * *}$ \\
& $\mathbf{( 0 . 3 0 6 )}$ & $\mathbf{( 0 . 1 1 6 )}$ & $\mathbf{( 0 . 4 3 6 )}$ & $\mathbf{( 0 . 5 0 8 )}$ \\
EC - error correction & $-0.147^{* * *}$ & $-0.226^{* * *}$ & $-0.173^{* * *}$ & $-0.252^{* * *}$ \\
term & $(0.025)$ & $(0.042)$ & $(0.026)$ & $(0.046)$ \\
$\Sigma($ d.gdp) & $-0.043^{*}$ & 0.001 & 0.013 & 0.034 \\
& $(0.044)$ & $(0.031)$ & $(0.050)$ & $(0.055)$ \\
$\Sigma($ d.yu $)$ & $0.315^{* * *}$ & $0.631^{* * *}$ & $0.271^{* *}$ & $0.495^{* * *}$ \\
& $(0.049)$ & $(0.071)$ & $(0.079)$ & $(0.108)$ \\
Constant & $1.718^{* * *}$ & $4.120^{* * *}$ & $1.884^{* * *}$ & $4.097^{* * *}$ \\
& $(0.231)$ & $(0.772)$ & $(0.199)$ & $(1.043)$ \\
No. of observations & 329 & 161 & 329 & 161 \\
\hline
\end{tabular}

Source: Author's calculations.

Note: *,**, *** means that the null hypothesis is rejected at 10, 5, and 1\% levels. Constant is included for each country. d denotes a differentiated variable. Short term coefficients are reported as sums of time lags. The values in brackets show the standard deviation.

Table 5b) shows the results for Model 2, where the relationship between total unemployment and GDP growth is estimated. The first two columns present the results obtained using Dynamic Fixed Effect Estimator, while in the last two columns are shown the results of the Mean Group Estimator. The estimated $\beta$ coefficient for both panels is statistically significant and negative, meaning that an increase in GDP will cause a decline in the total unemployment rate. The relationship is stronger in the panel composed of EU countries, and for any $1 \%$ increase in GDP, the total unemployment rate will decline by $1.46 \%$ or $1.83 \%$. In SEE panel, a $1 \%$ change in GDP will lead to only $0.25 \%$ or $0.87 \%$ decline in the unemployment rate of the total labor force.

The error correction term is also statistically significant and negative implying that the total 
unemployment is driven by the GDP growth, and the changes in GDP will cause changes in the total unemployment. Just like in Model 1, the results show that any change in GDP will cause quicker change in the total unemployment rate in SEE panel compared to EU panel, since the estimated values of the error correction term are higher for the SEE panel.

To select the most appropriate estimator we are using Hausman specification test, also known as Durbin Wu Hausman test or the Augmented regression test for endogeneity. This test determines the heterogeneity on the means of the variables and tests the null hypothesis of homogeneity. When the parameters are homogenous, the Hausman test prefers the DFE Estimator. If the null hypothesis of existing homogenous variables is rejected, then the MG estimator is more efficient. The results of the Hausman test are shown in Table 5. Given that the probability value is higher than 0.05 in three of four cases, the null hypothesis of homogeneity cannot be rejected. Hence, the test suggest that the DFE Estimator will be more efficient to estimate the relationship between unemployment, both total and youth, and GDP growth, in both panels of countries. It means that the results obtained using Dynamic Fixed Effect Estimator are more relevant in this research.

Table 6. Hausman Test

\begin{tabular}{lllll}
\hline & \multicolumn{2}{l}{ Youth unemployment and GDP } & \multicolumn{2}{l}{ Total unemployment and GDP } \\
\cline { 2 - 5 } & Chi-square & p-value & Chi-square & p-value \\
\hline EU panel & 0.03 & $0.8621^{*}$ & 0.36 & 0.5486 \\
SEE panel & 3.07 & 0.0797 & 0.45 & 0.5039 \\
\hline
\end{tabular}

Source: Author's calculations

Note: The specified model for estimating Hausman specification test is Hausman mg dfe, sigmamore. If $p<$ 0.05 the first specified estimator (Mean group estimator $(M G)$ in our case) is selected. * means that the model failed to meet the asymptotic assumptions of the Hausman test. Therefore, the model is specified as Hausman DFE mg, and in this case if $p<0.05$ the Dynamic Fixed Effect (DFE) Estimator is selected.

For both models and both estimators, two main conclusions can be drawn: 1. The Okun's coefficient is higher in the panel of EU countries and 2. The error correction term is higher in the panel of SEE countries, meaning that any imbalance in the relationship between unemployment and GDP will adjust faster in SEE countries compared to those in EU. A part of this result can be explained by the more flexible labor market institutions in the developing countries, as those that are a part of the SEE panel. The more flexible employment institutions mean that laws and policies that protect workers "allow" the employer to hire / fire employees more easily, and depending on the economic cycle, to adjust the number of employees according to the company's needs. The higher value of the Okun's coefficient in the EU panel is consistent with the other researches presented in Section 2 that in high-income countries, the relationship between unemployment and GDP is stronger compared to the poorer countries. This can be explained through the prism of unemployment type: the unemployment in developing countries is mainly structural rather than cyclical, meaning that there is higher 'skills gap' or mismatch between the skills supplied by the workers and those required by the 
employers. This is especially evident in the SEE countries that after their transition in early ' 90 s remained with poor educational system that produces incompetent staff, with knowledge and skills incompatible to the new technologies and labor market needs. Therefore, the response of the unemployment to the economic growth is smaller in SEE panel compared to the EU panel.

The comparison between the results obtained for both models show that there is a stronger relationship and faster adjustment between the GDP growth and youth unemployment, compared to the total unemployment. This can be supported with the fact that, in case of negative changes in the GDP (economy downturn), employers are likely to find it easier to fire young workers, who are less experienced and probably have temporary contract, compared to the older workers who work within the company longer and have greater experience. Opposite, in situation of economy upturn, any increase in the GDP will cause greater decrease of the youth unemployment rate rather than the total unemployment. Probably, it is easier to find new workers that match the employers' needs, from the bigger pool of unemployed young people, given that their unemployment rates are even double than the total unemployment rates in some countries of interest.

\section{Conclusion}

This paper investigates the relationship between the economic growth and the unemployment rates of total and youth population, in context of Okun's Law, in two panels of countries: 1) Panel composed of seven SEE countries and 2) Panel composed of fourteen EU countries whose unemployment rate of youth ages 15-24 in 2017 was below the average youth unemployment rate in EU of $18.9 \%$. The paper employs the difference model of the Okun's Law using Panel Autoregressive Distributed Lag Model, and data for the period 1991-2017. The analysis of the integrative characteristics of the variables shows that our series are likely to follow a stationary process, which means that they do not contain a unit root. It was a good ground for establishing co-integrative relationship between the series, whereas the test of Westerlund (2007) shows that in both panels there is a co-integrating relationship between unemployment rates and economic growth. Using two estimators, Mean Group and Dynamic Fixed Effects, we have established a long-run relationship between the variables of interest, showing that for both estimators and in both panels, there is a significant relationship between economic growth and unemployment rates. Thereby, a 1\% increase in the economic growth will cause a $2.5 \%$ and $0.4 \%$ decrease in the youth unemployment rates and $1.5 \%$ and $0.25 \%$ decrease in the total unemployment rates in EU and SEE panel respectively. The results show that the relationship between the variables is much weaker in the SEE panel, probably because the unemployment in developing countries is mainly structural rather than cyclical, meaning that there is higher 'skills gap' or mismatch between the skills supplied by the workers and those required by the employers. The error correction term is negative and statistically significant for all estimations, implying that the unemployment rates are driven by the economic growth, and the changes in GDP will cause changes in the unemployment of total and youth labor force. The error correction term has higher values for the SEE panel, and 
probably can be explained by the more flexible labor market institutions in the developing countries, which means that laws and policies that protect workers "allow" the employer to hire / fire employees more easily, according to the company's needs.

The second conclusion is that the youth unemployment rate is more sensitive to the economic cycle, as it was explained in the empirical analysis of the Okun's Law. It means that in case of changes in the economic growth, the unemployment rate of youth will notice major changes compared to the unemployment rate of general population, mainly because the companies face lower opportunity costs for firing/hiring young workers, who are less experienced, probably have temporary employment contracts and/or are less protected by the existing employment institutions.

\section{References}

Ball, L., Furceri, D., Leigh, D., \& Lounghani, P. (2019). Does one Law fit all? Cross-country evidence of Okun's Law. Open Economies Review, 30(7), 841-874. https://doi.org/10.1007/s11079-019-09549-3

Bell, D., \& Blanchflower, D. (2011). Young People and the Great Recession. Oxford Review of Economic Policy, 27(2), 241-267. https://doi.org/10.1093/oxrep/grr011

Boulton, T. (2010). Test of Okun's Law for the 10 Eastern European counties. London Metropolitan Business School, Economics Subject Group. Retrieved from https://www.ukdataservice.ac.uk/media/263140/boulton-paper.pdf

Butkus, M., \& Seputiene J. (2019). The output gap and youth unemployment: An analysis $\begin{array}{lllll}\text { based on } \quad \text { Okun's } & \text { Law. }\end{array}$ https://doi.org/10.3390/economies7040108

Dietrich, H. (2012). Youth unemployment in Europe: Theoretical considerations and empirical findings. Friedrich Ebert Stiftung Studies. Retrieved from https://library.fes.de/pdffiles/id/ipa/09227.pdf

Dunsch, S. (2016). Okun's Law and youth unemployment in Germany and Poland. International Journal of Management and Economics, 49(1), 34-57. https://doi.org/10.1515/ijme-2016-0003

Farlore, T., Ferro, E., \& Gutierrez, V. (2017). Job creation in the private sector: An exploratory assessment of patterns and determinants at the macro, sector, and firm levels. Jobs Working Paper Issue No. 5. The World Bank. Retrieved from http://documents.worldbank.org/curated/en/214701505483434627/pdf/AUS22807-WPPUBLIC-24-8-2017-18-50-23-JobCreationThomasFarole.pdf

Gocer, I., \& Erdal, L. (2015). The relationship between youth unemployment and economic growth in Central and Eastern European countries: An empirical analysis. Journal of the Faculty of Economics and Administrative Sciences, 5(1), 173-188. 
Gordon, R. (1985). Unemployment and potential output in 1980s. Brookings Papers on Economic Activity, 2(2), 537-568. https://doi.org/10.2307/2534438

Hanusch, M. (2013). Jobless growth? Okun's Law in East Asia. Journal of International Commerce, Economics and Policy, 4(3), 1-14. https://doi.org/10.1142/S1793993313500142

Harris, R., \& Sollis, R. (2003). Applied Time Series Modenling and Forecasting. Chichester: John Wiley \& Sons Ltd.

Holmes, M., Otero, J., \& Panagiotidis, T. (2010). Are EU budget deficits stationary? Empirical Economics, 38, 767-778. https://doi.org/10.1007/s00181-009-0289-3

Huang, H., \& Yeh, C. (2013). Okun's Law in panels of countries and states. Applied Economics, 45(2), 191-199. https://doi.org/10.1080/00036846.2011.597725

Kaufman, R. (1988). An international comparison of Okun's Law. Journal of Comparative Economics, 12(2), 182-203. https://doi.org/10.1016/0147-5967(88)90002-9

Knoester, A. (1986). Okun' Law revisited. Weltwirtschaftliches Archiv, 122, 657-666. https://doi.org/10.1007/BF02707853

Lee, J. (2000). The robustness of Okun's Law: Evidence from OECD countries. Journal of Macroeconomics, 22(2), 331-356. https://doi.org/10.1016/S0164-0704(00)00135-X

Maddala, G. S., \& Wu, S. (1999). A comparative study of unit root tests with panel data and a new simple test, Oxford bulletin of economics and statistics, 61(special issue), 631-652. https://doi.org/10.1111/1468-0084.0610s1631

Moosa, A. (1997). A cross-country comparison of Okun's coefficient. Journal of Comparative Economics, 24, 335-356. https://doi.org/10.1006/jcec.1997.1433

Novak, D., \& Darko, L. (2019). Okun's Law over the business cycle: Does it change in the EU countries after the financial crisis? Prague Economic Papers, 2019(2), 235-254. https://doi.org/10.18267/j.pep.694

O'Higgins, N. (1997). The challenge of youth unemployment. International Social Security Review, 50(4), 63-93. https://doi.org/10.1111/j.1468-246X.1997.tb01084.x

Ozel, H., Sezgin, F., \& Topkaya, O. (2013). Investigation of economic growth and unemployment relationships in G7 countries using panel regression analysis. International Journal of Business and Social Science, 4(6), 163-171.

Pesaran, M. H. (2007). A simple panel unit root test in the presence of cross-section dependence. Journal of Applied Econometrics, 22(2), 265-312. https://doi.org/10.1002/jae.951

Pesaran, M. H., \& Shin, Y. (1999). An Autoregressive Distributed Lag Modelling Approach to Co-integration Analysis. Econometrics and Economic Theory in the 20st Century: The Ragnar Frisch Centennial Symposium. https://doi.org/10.1017/CCOL0521633230.011 
Pesaran, M. H., \& Smith, Y. (1995). Estimating long-run relationships from dynamic heterogeneous panels. Journal of Econometrics, 68(1), 79-113. https://doi.org/10.1016/0304-4076(94)01644-F

Pesaran, M. H. (2004). General diagnostic tests for cross section dependence in panels. IZA discussion paper, 1240. Retrieved from http://ftp.iza.org/dp1240.pdf

Pesaran, M. H., Shin, Y., \& Smith, R. (1999). Bounds testing approaches to the analysis of level relationships. Journal of Applied Econometrics, 16(3), 289-326. https://doi.org/ 10.1002/jae.616

Pesaran, M. H., Shin, Y., \& Smith, R. (1999). Pooled mean group estimation of dynamic heterogeneous panels. Journal of the American Statistical Association, 94, 289-326. https://doi.org/ 10.1080/01621459.1999.10474156

Smith, G. (1974). Okun's Law revisited. Cowles Foundation Discussion Paper No. 380, Cowles Foundation for Research in Economics at Yale University. Retrieved from https://cowles.yale.edu/sites/default/files/files/pub/d03/d0380.pdf

Soylu, O., Cakmak, I., \& Okur, F. (2018). Economic growth and unemployment issues: Panel data analysis in Eastern European countries. Journal of International Studies, 11(1), 93107. https://doi.org/10.14254/2071-8330.2018/11-1/7

Unt, M. (2012). Boom and bust effects on youth unemployment in Estonia. Friedrich EbertStiffung International Policy Analysis. Retrieved from http://library.fes.de/pdffiles/id/09473.pdf

Vaskez, I., \& Porcnik, T. (2019). The Human Freedom Index 2019. Retrieved from https://www.cato.org/human-freedom-index-new

Westerlund, J. (2007). Testing for Error correction in panel data. Oxford bulletin of economics and statistics, 69(6), 709-748. https://doi.org/10.1111/j.1468-0084.2007.00477.x

Zanin, L. (2016). The pyramid of Okun's coefficient for Italy. Empirica, 45(1), 17-28. https://doi.org/10.1007/s10663-016-9343-5

\section{Notes}

Note 1. Kosovo and Montenegro are also part of the SEE countries, but since the lack of data, these two countries are excluded from this research.

\section{Copyright Disclaimer}

Copyright for this article is retained by the author(s), with first publication rights granted to the journal.

This is an open-access article distributed under the terms and conditions of the Creative Commons Attribution license (http://creativecommons.org/licenses/by/3.0/). 